\title{
SAKRALISASI PEMBUKAAN UUD 1945
}

\author{
Oleh: Wahyu Pambudi, M.Pd
}

Email: wahyu.pambudi@gmail.com

\begin{abstract}
ABSTRAK
Pembukaan Undang-undang Dasar 1945 telah lama di anggap sebagai staatsidee, dan oleh karenanya tidak boleh dirubah, merubahnya berarti merubah dasar negara. Namun kejanggalan-kejanggalan yang terdapat dalam Pembukaan Undang-undang Dasar itu menimbulkan beberapa pertanyaan dalam artikel ini, antara lain: (1) Bagaimanakah Staatsidee Negara Kesatuan Republik Indonesia? (2) Bagaimanakah kejanggalan-kejanggalan Pembukaan UUD Negara Kesatuan Republik Indonesia? (3) Bagaimanakah kemungkinan amandemen terhadap Pembukaan UUD Negara Kesatuan Republik Indonesia? Adapun metode yang digunakan dalam penulisan artikel ini adalah studi literatur, yaitu mencari sumber-sumber dari buku-buku yang relevan dengan topik yang dibahas. Selain itu, digunakan juga sumber internet sebagai referensi penunjang yang melengkapi sumber-sumber kepustakaan. Kesimpulan yang didapat antara lain: Pertama, Staatsidee Negara Kesatuan Republik Indonesia tidak terdapat dalam Proklamasi, melainkan dalam Pembukaan UUD 1945. Namun demikian itu tidak serta merta menjadi alasan bahwa Pembukaan itu sakral karena mengandung staatsidee, karena perubahan atau amandemen terhadapnya telah dijamin dalam Undang-Undan Dasar. Kedua, Kejanggalan-kejanggalan Pembukaan UUD Negara Kesatuan Republik Indonesia antara lain terdapat ambigu tentang pernyataan kemerdekaan antara pada Proklamasi atau Pembukaan UUD 1945. Kejanggalan yang lain adalah inkonsistensi penggunaan kata Allah dan Tuhan. Kejanggalan selanjutnya adalah panggantian terhadap naskah pembukaan UUD sehingga berarti pula penggantian terhadap staatsidee yaitu Pancasila. Ketiga, Amandemen terhadap Pembukaan UUD Negara Kesatuan Republik Indonesia adalah kemungkinan yang rasional dan berlandaskan hukum. Sebaliknya pengsakralan terhadapnya adalah sebuah mitos yang tidak berdasar hukum. Kejanggalan pembukaan UUD 1945 dan kemungkinan tuntutan zaman yang berbeda seharusnya memungkinkan untuk tetap memberikan peluang terhadap Amandemen UUD, termasuk didalamnya adalah Pembukaan.
\end{abstract}

Kata kunci: Staatsidee, Amandemen UUD

\section{A. LATAR BELAKANG}

Pembukaan Undang-undang Dasar 1945 telah lama di anggap sebagai staatsidee, dan oleh karenanya tidak boleh dirubah, merubahnya berarti merubah dasar negara. Namun kejanggalan-kejanggalan yang terdapat dalam Pembukaan Undang-undang Dasar itu menimbulkan beberapa pertanyaan. Misalnya kontradiksi penggunaan kata Allah pada alinea ke-3 dan Tuhan pada alinea ke-4 Pembukaan UUD 1945, hanya sebuah kata memang, tetapi ini mengandung makna yang fundamental dalam kehidupan berbangsa dan bernegara. Permasalahan itu meskipun sederhana, mencerminkan seperti apa bentuk bangsa yang kita sepakati, bentuk negara seperti apa yang kita inginkan.

Kenyataan bahwa pembukaan Undang-undang Dasar telah berubah sebanyak tiga kali, masing-masing melalui Konstitusi RIS 1949, UUDS 1950, dan Dekrit Presiden 5 Juli 1959 merupakan contoh bagaimana dinamika bangsa Indonesia menuntut penyesuaian-penyesuaian tertentu. Hal itu termasuk terhadap Pembukaan UUD, meskipun konon pembukaan itu mengandung staatsidee yang sakral.

Penyesuaian-penyesuaian

terhadap kondisi bangsa memang memungkinkan untuk melakukan amandemen terhadap UUD, namun bagaimana jika amandemen tersebut berbenturan dengan hal yang "sakral"? 
Artikel ini mencoba menganalisis permasalahan tersebut. Termasuk memberikan jawaban apakah staatsidee atau teks atas staatsidee tersebut yang lebih sakral.

Berdasarkan latar belakang diatas, maka penulis merumuskan masalah dalam beberapa pertanyaan, antara lain: (1) Bagaimanakah Staatsidee Negara Kesatuan Republik Indonesia? (2) Bagaimanakah kejanggalan-kejanggalan Pembukaan UUD Negara Kesatuan Republik Indonesia? (3) Bagaimanakah kemungkinan amandemen terhadap Pembukaan UUD UUD Negara Kesatuan Republik Indonesia?

Adapun metode yang digunakan dalam penulisan artikel ini adalah studi literatur, yaitu mencari sumber-sumber dari buku-buku yang relevan dengan topik yang dibahas. Selain itu, digunakan juga sumber internet sebagai referensi penunjang yang melengkapi sumber-sumber kepustakaan.

\section{B. STAATSIDEE DAN DEKLARASI KEMERDEKAAN}

Staatsidee dalam bahasa Indonesia sering diterjemahkan sebagai cita negara. Kata idee dapat diterjemahkan dengan cita. Cita ialah gagasan, rasa, cipta, pikiran. Menurut Oppenheim, cita negara yaitu hakikat yang paling dalam dari negara (de staats diepstewezen), sebagai kekuatan yang membentuk negara (de statenvormende kraccht). Elemen kunci dari teorinya adalah bahwa kepentingan umum akan selalu mendahului kepentingan individu dan kelompok. Dari pendapat tersebut dapat disimpulkan bahwa cita negara ialah hakikat negara yang paling dalam yang dapat memberi bentuk pada negara atau hakikat negara yang menetapkan bentuk negara (Raharjo, 2013).

$$
\text { Pengertian staatsidee }
$$

merupakan pengertian penting dalam pendekatan positivis terhadap hukum konstitusional. Menurut doktrin ini, negara merupakan sebuah herarki hukum (yang dinamakan norma-norma hukum) dimana puncaknya disebut staatsidee

(grundnorm,

staatsfundamentalnorm, atau norma dasar). Menurut Nawiasky isi norma dasar ialah norma yang merupakan dasar (landasan dasar filosofis) bagi pembentukan konstitusi termasuk norma perubahannya. Hakekat hukum suatu norma dasar ialah syarat bagi berlakunya suatu konstitusi. Ia ada terlebih dahulu sebelum adanya konstitusi (Raharjo, 2013).

Sedangkan Jimly Asshiddiqie berpendapat bahwa tujuan-tujuan atau cita-cita bersama yang biasa juga disebut sebagai falsafah kenegaraan atau staatsidee (cita negara) yang berfungsi sebagai filosofische grondslag dan common platforms atau kalimatun sawa di antara sesama warga masyarakat dalam konteks kehidupan bernegara (Asshiddiqie, TT: 6).

Di Indonesia, dasar-dasar filosofis yang dimaksudkan itulah yang biasa disebut sebagai Pancasila yang berarti lima sila atau lima prinsip dasar untuk mencapai atau mewujudkan empat tujuan bernegara. Lima prinsip dasar Pancasila itu mencakup sila atau prinsip (i) Ketuhanan Yang Maha Esa; (ii) Kemanusiaan yang Adil dan Beradab; (iii) Persatuan Indonesia; (iv) Kerakyatan yang Dipimpin oleh Hikmat Kebijaksanaan dalam Permusyawaratan/Perwakilan; dan (v) Keadilan Sosial bagi Seluruh Rakyat Indonesia. Kelima sila tersebut dipakai sebagai dasar filosofis-ideologis untuk mewujudkan empat tujuan atau cita-cita ideal bernegara, yaitu: (i) melindungi segenap bangsa Indonesia dan seluruh tumpah darah Indonesia; (ii) meningkatkan kesejahteraan umum; (ii) mencerdaskan kehidupan bangsa; dan (iv) ikut melaksanakan ketertiban dunia berdasarkan kemerdekaan, perdamaian yang abadi, dan keadilan sosial (Asshiddiqie, TT: 6).

Dari penjelasan diatas kita mendapatkan setidaknya dua poin penting: pertama, bahwa staatsidee adalah dasar falsafah bernegara; kedua, di Indonesia dasar falsafah bernegara itu adalah Pancasila. 
Ada beberapa syarat minimal yang harus dipenuhi agar sesuatu dapat disebut sebagai negara. Syarat tersebut berlaku secara umum dan merupakan unsur yang penting. Syarat-syarat tersebut digolongkan menjadi dua, yaitu unsur konstitutif dan unsur deklaratif. Unsur konstitutif terbentuknya negara adalah unsur yang mutlak harus ada pada saat negara didirikan. Unsur konstitutif ini meliputi rakyat, wilayah, dan pemerintah yang berdaulat. Adapun unsur deklaratif adalah unsur yang tidak mutlak ada pada saat negara berdiri, tetapi unsur ini boleh dipenuhi atau menyusul dipenui setelah negara berdiri. Unsur deklaratif adalah pengakuan dari negara lain (Denni, 2013).

Menurut Oppenheimer dan Lauterpacht, suatu Negara harus memenuhi syarat-syarat: (a) rakyat yang bersatu, (b) daerah atau wilayah, (c) pemerintahan yang berdaulat, (d) pengakuan dari negara lain. Sedangkan menurut Konvensi Montevideo tahun 1933, yang merupakan Konvensi Hukum Internasional, Negara harus mempunyai empat unsur konsititutif, yaitu: (a) harus ada penghuni (rakyat, penduduk, warga Negara) atau bangsa (staatvolk), (b) harus ada wilayah atau lingkungan kekuasaan, (c) harus ada kekuasaan tertinggi (penguasa yang berdaulat) atau pemerintahan yang berdaulat, (d) kesanggupan berhubungan dengan Negara-negara lain.

Untuk menyatakan unsur konstitutif tersebut sebuah negara yang baru berdiri akan memulai dengan deklarasi pembentukan negara. Beberapa negara yang terbentuk secara sekunder, yaitu mendirikan negara sebagai pengganti negara yang telah ada sebelumnya akan memulai dengan sebuah proklamasi kemerdekaan. Seperti Amerika, India dan Perancis, Indonesia menyatakan membentuk pemerintahannya sendiri terhitung sejak proklamasi kemerdekaannya. Secara umum terdapat tiga hal yang seharusnya termuat dalam deklarasi kemerdekaan sebuah negara, yaitu: pernyataan sebagai negara merdeka, alasan merdeka, dan tujuan merdeka. Dan oleh karena ciri-ciri itu, sebuah deklarasi kemerdekaan seharusnya memuat staatsidee.

\section{STAATSIDEE INDONESIA: PROKLAMASI ATAU PEMBUKAAN UUD 1945?}

Dalam kasus terbentuknya Negara Kesatuan Republik Indonesia staatsidee tidak termaktub dalam deklarasi kemerdekaan, melainkan termaktub dalam Pembukaan UndangUndang Dasar 1945. Dilihat dari sejarah terbentuknya, negara Indonesia memiliki banyak kemiripan dengan terbentuknya negara Amerika, sehingga berpeluang memiliki pola staatsidee yang sama. Dalam arti staatsidee seharusnya termaktub dalam Proklamasi Kemerdekaan. Amerika maupun Indonesia memerdekakan diri dari negara yang menjajahnya dan menjadikan Proklamasi (Declaration of Independence di Amerika) sebagai tonggak pemisahan diri itu. Hal ini berbeda jika dibandingkan dengan negara yang memperoleh kemerdekaannya dengan "dimerdekakan" oleh negara penjajahnya, misalnya India. Pernyataan merdeka itu terwujud dalam sebuah undang-undang dari negara penjajah (Inggris) yang menyatakan "memerdekakan" sehingga bagi negara yang dimerdekakan memerlukan mencantumkan staatsidee dalam pembukaan Undang-Undang Dasarnya. Tapi kenyataanya pola staatsidee Indonesia justru memiliki banyak kemiripan dengan India. Oleh karena itu United States Declaration of Independence (1776) dan Preamble of the Constitution of United States (1787) serta Indian Independence Act 1947 dan Preamble of the Constitution of India (1949) akan digunakan sebagai bahan perbandingan dalam artikel ini.

Proklamasi Kemerdekaan Indonesia tidak mencantumkan Staatsidee, melainkan hanya sebuah pernyataan untuk merdeka. Apa alasan untuk merdeka dan apa tujuan 
kemerdekaan itu sama sekali tidak tercantum. Seperti terlihat dalam teks proklamasi berikut:

Kami bangsa Indonesia dengan ini menyatakan kemerdekaan Indonesia. Hal-hal yang mengenai pemindahan kekuasaan dan lain-lain, diselenggarakan dengan cara seksama dan dalam tempo yang sesingkat-singkatnya.

Pertanyaannya adalah kenapa para pendiri bangsa ketika itu tidak mencantumkan staatsidee dalam Proklamasi? Sejarah mencatat bahwa hal tersebut sebenarnya telah direncanakan. Pada tanggal 22 Juni 1945 "Panitia Sembilan" dari Badan Penyelidik Usaha-usaha Persiapan Kemerdekaan Indonesia (BPUPKI) telah menghasilkan rumusan dasar negara Republik Indonesia yang kemudian dikenal sebagai "Piagam Jakarta" atau "Jakarta Charter". Berikut adalah redaksi dari Piagam Jakarta tersebut:

Bahwa sesungguhnya kemerdekaan itu ialah hak segala bangsa, dan oleh sebab itu maka penjajahan di atas dunia harus dihapuskan, karena tidak sesuai dengan peri-kemanusiaan dan perikeadilan.

Dan perjuangan pergerakan kemerdekaan Indonesia telah sampailah kepada saat yang berbahagia dengan selamat sentosa mengantarkan rakyat Indonesia kedepan pintu-gerbang negara Indonesia, yang merdeka, bersatu, berdaulat, adil dan makmur.

Atas berkat rahmat Allah Yang Maha Kuasa, dan dengan didorongkan oleh keinginan yang luhur, supaya berkehidupan kebangsaan yang bebas, maka rakyat Indonesia dengan ini menyatakan kemerdekaannya.

Kemudian daripada itu, untuk membentuk suatu pemerintah negara Indonesia yang melindungi segenap bangsa Indonesia dan seluruh tumpah darah Indonesia, dan untuk memajukan kesejahteraan umum, mencerdaskan kehidupan bangsa, dan ikut melaksanakan ketertiban dunia yang berdasarkan kemerdekaan, perdamaian abadi dan keadilan sosial, maka disusunlah kemerdekaan kebangsaan Indonesia itu dalam suatu Hukum Dasar Negara Indonesia, yang terbentuk dalam suatu susunan negara Republik Indonesia yang berkedaulatan rakyat, dengan berdasar kepada: Ketuhanan, dengan kewajiban menjalankan syari'at Islam bagi pemeluk-pemeluknya, menurut dasar kemanusiaan yang adil dan beradab, persatuan Indonesia, dan kerakyatan yang dipimpin oleh hikmat, kebijaksanaan dalam permusyarawaratan/ perwakilan, serta dengan mewujudkan suatu keadilan sosial bagi seluruh rakyat Indonesia.

Kemudian pada tanggal 14 Juli 1945, sidang pleno BPUPKI menerima laporan panitia Perancang UndangUndang Dasar, yang dibacakan oleh ketua panitianya sendiri, Ir. Soekarno. Dalam laporan tersebut membahas mengenai rancangan Undang-Undang Dasar yang di dalamnya tercantum tiga masalah pokok yaitu: Pernyataan tentang Indonesia Merdeka (Proklamasi), Pembukaan UndangUndang Dasar, dan Batang tubuh Undang-Undang Dasar. Konsep proklamasi kemerdekaan negara Indonesia baru rencananya akan disusun dengan mengambil tiga alenia pertama "Piagam Jakarta", sedangkan konsep Pembukaan Undang-Undang Dasar hampir seluruhnya diambil dari alinea keempat "Piagam Jakarta" (Wikipedia, 2014).

Namun yang terjadi selanjutnya berlainan benar dengan apa yang direncanakan. Tekanan golongan muda yang dipelopori oleh Sukarni untuk memprokamirkan kemerdekaan selekas mungkin dan tanpa campur tangan Jepang memicu peristiwa Rengasdengklok. Hasrat sebagian rakyat yang mengidamkan 
kemerdekaan $100 \%$ tanpa campur tangan Jepang membuat mereka menolak segala peran atas nama institusi BPUPKI dan PPKI (Panitia Persiapan Kemerdeaan Indonesia) karena keduanya adalah bentukan Jepang. Kemudian keputusan yang diambil oleh para Founding Fathers adalah membuat naskah proklamasi yang sama sekali baru, untuk mendamaikan golongan tua dan golongan muda. Jadilah kemudian naskah proklamasi seperti yang kita kenal saat ini, sebuah naskah yang dibuat semalam sebelum hari Proklamasi, 17 Agustus 1945. Itu berarti naskah kemerdekaan Indonesia hanya dikonsep dalam beberapa jam saja.

Konsep yang dibuat begitu singkat, membuat naskah tersebut sangat sederhana, dan bahkan tidak mencantumkan staatsidee negara Indonesia. Dilihat dari konsepnya "Piagam Jakarta" memang lebih ideal jika digunakan sebagai teks Proklamasi, karena didalamnya tercantum pernyataan Indonesia merdeka, alasan Indonesia merdeka, staatsidee Indonesia, dan Tujuan negara Indonesia merdeka. Maka solusi yang diambil oleh para pendiri bangsa adalah meletakkan "Piagam Jakarta" sebagai naskah Pembukaan Undang-Undang Dasar 1945, dengan beberapa penyesuaian kecil namun prinsipil. Penyesuaian kecil namun prinsipil itu, atau juga luputnya penyesuaian kecil yang dibutuhkan, kemudian justru membuat teks Pembukan UUD 1945 menyisakan beberapa kejanggalan. Namun secara umum, para pendiri bangsa sepakat untuk meletakkan staatsidee Indonesia dalam teks Pembukaan UUD 1945 bukan dalam teks Proklamasi.

\section{KEJANGGALAN-KEJANGGALAN PEMBUKAAN UUD 1945}

Pembukaan UUD 1945 memang diadopsi dari "Piagam Jakarta", namun bagaimanapun juga ia telah diletakkan sebagai "pengantar" untuk sebuah Undang Undang Dasar. Selain itu ia merupakan pelengkap dari proklamasi karena mencantumkan alasan Indonesia merdeka, staatsidee Indonesia dan Tujuan negara Indonesia merdeka, yang belum tercantum dalam Proklamasi Kemerdekaan. Namun seharusnya itu tidak membuat tumpang tindih antara keduanya. Berikut adalah teks Pembukaan UUD 1945 yang akan dianalisis beberapa kejanggalannya:

$$
\text { Bahwa sesungguhnya }
$$

kemerdekaan itu ialah hak segala bangsa dan oleh sebab itu, maka penjajahan di atas dunia harus dihapuskan, karena tidak sesuai dengan peri-kemanusiaan dan perikeadilan.

Dan perjuangan pergerakan kemerdekaan Indonesia telah sampailah kepada saat yang berbahagia dengan selamat sentausa mengantarkan rakyat Indonesia ke depan pintu gerbang negara Indonesia, yang merdeka, bersatu, berdaulat, adil dan makmur.

Atas berkat rahmat Allah Yang Maha Kuasa dan dengan didorongkan oleh keinginan luhur, supaya berkehidupan kebangsaan yang bebas, maka rakyat Indonesia menyatakan dengan ini kemerdekaannya.

Kemudian daripada itu untuk membentuk suatu pemerintah negara Indonesia yang melindungi segenap bangsa Indonesia dan seluruh tumpah darah Indonesia, dan untuk memajukan kesejahteraan umum, mencerdaskan kehidupan bangsa, dan ikut melaksanakan ketertiban dunia yang berdasarkan kemerdekaan, perdamaian abadi dan keadilan sosial, maka disusunlah kemerdekaan kebangsaan Indonesia itu dalam suatu Undang-Undang Dasar Negara Indonesia, yang terbentuk dalam suatu susunan negara Republik Indonesia yang berkedaulatan rakyat, dengan berdasar kepada: Ketuhanan Yang Maha Esa, kemanusiaan yang adil dan beradab, persatuan Indonesia, dan kerakyatan yang dipimpin oleh 
hikmat kebijaksanaan dalam permusyarawaratan/perwakilan, serta dengan mewujudkan suatu keadilan sosial bagi seluruh rakyat Indonesia.

\section{Merdeka 17 Agustus atau 18 Agustus 1945?}

Dalam teks tersebut terdapat beberapa kejanggalan utama, antara lain terdapat pada frasa terakhir aliena ke-3, yaitu tercantum: "maka rakyat Indonesia menyatakan dengan ini kemerdekaannya". Frasa itu membuat ambigu antara teks ini sebagai pembukaan UUD atau teks ini sebagai sebuah teks proklamasi? Seperti kita ketahui Indonesia telah menyatakan merdeka melalui Proklamasi kemerdekaan 17 Agustus 1945, lalu untuk apa menyatakan merdeka lagi pada tanggal 18 Agustus 1945, saat UUD 1945 (dalam hal ini tentu termasuk Pembukaan) di sahkan?

Tentu secara historis hal ini tidak terlepas dari sidang-sidang BPUPKI yang merancang "Piagam Jakarta" itu sebagai naskah Proklamasi. Namun jika memang kesepakatan baru bahwa naskah tersebut dijadikan sebagai teks pembukaan UUD, maka mutlak diperlukan sebuah "penyesuaianpenyesuaian kecil". Bahkan beberapa penyesuaian itu menyentuh hal yang sangat prinsipil, Seperti yang terlihat dalam sidang PPKI 18 Agustus 1945, dimana terdapat beberapa perubahan redaksi seperti: "Hukum Dasar" menjadi "UndangUndang Dasar", "Ketuhanan, dengan kewajiban menjalankan syari'at Islam bagi pemeluk-pemeluknya" menjadi "Ketuhanan Yang Maha Esa".

bahwa terjadinya dua kali pernyataan kemerdekaan ini adalah sebuah kelalaian atau bahkan pengabaian, dalam pembahasan dalam sidang PPKI 18 Agustus 1945. Dan tentu saja, kejanggalan ini tetap perlu untuk mendapat pelurusan. Misalnya mengamandemen Pembukaan UUD tersebut sehingga berbunyi: "maka rakyat Indonesia pada tanggal 17 Agustus 1945 telah menyatakan kemerdekaannya" atau "maka rakyat Indonesia telah menyatakan kemerdekaannya".

Tentu banyak alternatif redaksi yang dapat digunakan, namun yang prinsip adalah teks Pembukaan tersebut mengandung kejanggalan dan perlu diadakan perubahan, oleh karenanya opsi melakukan amandemen terhadap Pembukan itu adalah opsi yang sangat rasional.

\section{Tuhan atau Allah?}

Kejanggalan berikutnya adalah penggunaan kata Allah pada alenia ke-3 sehingga frasa itu berbunyi "Atas berkat rahmat Allah Yang Maha Kuasa...". hal ini akan kontradiktif dengan alinea ke-4 dimana disana terletak staatsidee dan dengan jelas staatsidee itu menyebutkan "Ketuhanan Yang Maha Esa".

Jika benar bahwa semangat UUD 1945 sebagaimana sidang 18 Agustus 1945 adalah menghindari bentuk negara Islam, seperti yang menjiwai perubahan redaksi sila pertama Pancasila, mengapa dalam pembukaan alinea ke-3 tetap mencantumkan "atas berkat rakhmat Allah yang Maha Kuasa..."?. Keganjilan ini cukup mengusik, meskipun kata "Allah" dapat diterima oleh tiga agama terbesar di Indonesia: Islam, Kristen, dan Katolik, akan tetapi bagaimana dengan Hindu dan Budha? Serta dewasa ini Konghucu?

Menarik untuk mengutip artikel dari J.W. Sulandra, S.H. berjudul "Hubungan Antara Proklamasi 17 Agustus 1945 dan Pembukaan dan Batang Tubuh UUD 1945" (dalam Darmodiharjo, Ed., 1991: 192) sebagai berikut:

"Menurut redaksi pembukaan terakhir yang ditetapkan oleh 
Panitia

Persiapan

Kemerdekaan Indonesia pada

18 Agustus 1945 istilah Allah diganti dengan Tuhan dan tidak ada penjelasan mengapa dalam Berita Republik Indonesia tahun II nomor 7 disebutkan Allah. Kiranya dengan mendalami isi pengertian yang terkandung didalamnya tidaklah merupakan persoalan (lagi)."

Berita Republik Indonesia tahun II No. 7 adalah berita (publikasi) negara yang memuat naskah UUD 1945 yang dianggap paling otentik dan digunakan sebagai acuan teks UUD (sebelum di amandemen) hingga saat ini. Dari artikel tersebut terlihat bagaimana kita menyederhankan permasalahan dan mengabaikan minoritas. Kejanggalan tersebut linier pula dengan pasal 9 UUD 1945 yang memuat sumpah Presiden dan Wakil Presiden dengan redaksi: "Demi Allah, saya bersumpah...". seolaholah Presiden dan Wakil Presiden pasti beragama Samawi (Islam, Kristen, Katolik), kalaupun nanti ada Presiden dan Wakil Presiden bergama lain, ia cukup berjanji dengan sungguh-sungguh, tidak perlu bersumpah menurut agamanya. Pendapat menarik dikemukakan oleh Prof. Dr. Hazairin, S.H. dimana dinyatakan bahwa Allah adalah penyebutan spesifik untuk nama Tuhan yang dimaksud. Allah adalah nama pribadi bagi Tuhan YME, alasannya menyebutkan Tuhan tanpa nama dapat menimbulkan salah paham (Hazairin, 1990: 74, 82). Yang dimaksud adalah misalnya akan rancu antara Tuhan Allah dan Tuhan Yesus bagi orang Kristen dan Tuhan Indera dan Tuhan Siwa bagi orang Hindu Bali.

Menurut penulis, pendapat itu terlalu naif, sangat lemah dan mengandung banyak pertanyaan mengganjal. Misalnya jika memang itu menimbulkan kerancuan, kenapa dalam alinea yang lain tertulis "Ketuhanan Yang Maha Esa"? kenapa bukan "Allah Yang Maha Esa"? dalam sidang PPKI jelas frasa kedua tersebut akan ditolak sebab bertentangan dengan semangat untuk menghindari bentuk negara Islam. Jika memang harus memilih kenapa yang dipilih adalah nama Allah? Bukan Yesus? Bukan Siwa? Apakah hanya karena Islam mayoritas? Sekali lagi dalam sidang 18 Agustus 1945, para pendiri bangsa telah sepakat menghindari bentuk negara Islam.

Oleh sebab itu menggunakan kata Tuhan akan lebih dapat diterima oleh semua agama di Indonesia. Misalkan frasa itu menjadi "Atas berkat rahmat Tuhan Yang Maha Kuasa..", tidak akan mengecilkan orang Islam bahwa Tuhan yang dimaksud adalah Allah, pun demikian dengan agama-agama lain. Sebagaimana pula Staatsidee "Ketuhanan Yang Maha Esa", bahwa ia menjamin orang Islam untuk menjalankan syariat Islam, orang Kristen menjalankan syariat Kristen, orang Hindu menjalankan syariat Hindu, dan seterusnya.

\section{Perubahan-perubahan Redaksi Pembukaan UUD}

Selanjutnya adalah kenyatan bahwa dalam perjalanan Negara Indonesia masa transisi RI-RISNKRI, bahwa Pembukaan UUD telah mengalami beberapa kali perubahan. Perubahan itu dilakukan dalam bentuk utuh, maka yang terjadi adalah mengganti Pembukaan UUD, bukan sekedar amandemen. Jika ditinjau dari Pembukaan mengandung staatsidee, maka pada dasarnya staatsidee Indonesia telah mengalami penggantian pula, seperti kita cermati dibawah ini:

“...maka disusunlah
kemerdekaan kebangsaan
Indonesia Itu dalam suatu
Undang-undang $\quad$ Dasar


Negara Indonesia, yang terbentuk dalam suatu susunan negara Republik Indonesia yang berkedaulatan Rakyat, dengan berdasar kepada: Ketuhanan Yang Maha Esa, Kemanusiaan yang adil dan beradab, Persatuan Indonesia, dan Kerakyatan yang dipimpin oleh hikmat kebijaksanaan dalam Permusyawaratan/

Perwakilan, serta dengan mewujudkan suatu keadilan sosial bagi seluruh Rakyat Indonesia."

- Pembukaan UUD 1945

"Maka demi ini kami menyusun kemerdekaan kami itu dalam suatu Piagam Negara yang berbentuk Republik Federasi, berdasarkan pengakuan keTuhanan Yang Maha Esa, perikemanusiaan,

kebangsaan, kerakyatan dan keadilan sosial."

- Mukadimah Konstitusi RIS 1949

"Maka demi ini kami menyusun kemerdekaan kami itu dalam suatu piagam Negara yang berbentuk republik-kesatuan,

berdasarkan pengakuan berdasarkan pengakuan keTuhanan Yang Maha Esa, perikemanusiaan,

kebangsaan, kerakyatan dan keadilan sosial, untuk mewujudkan kebahagiaan, kesejahteraan, perdamaian dan kemerdekaan dalam masyarakat dan Negarahukum Indonesia Merdeka yang berdaulat sempurna."

- Mukadimah UUDS 1950

Dari ketiga naskah pembukaan UUD tersebut kita mendapati perubahan redaksi terhadap Pancasila pada mukadimah konstitusi RIS 1949. Perubahan ini sangat disayangkan meskipun pada umumnya dapat dimaklumi. Alasanya terutama adalah bahwa RIS dan seperti hasil KMB (Konferensi Meja Bundar) lainnya merupakan sebuah manuver politik dan taktik diplomasi. Lagipula ketika RIS didirikan dengan UUD RIS, sebagai negara bagian di dalamnya RI masih menggunakan UUD 1945. Sehingga hal itu dianggap sebagai transisi sementara, seperti yang kemudian memang dilakukan: dalam tempo kurang dari satu tahun, transisi pembentukan NKRI dari RIS telah dilaksanakan pada 17 Agustus 1950. Namun dalam UUDS 1950 ternyata perubahan redaksi terhadap Pancasila tersebut justru dipertahankan dalam Mukadimahnya.

Perubahan susunan kata-kata dari kelima sila Pancasila inilah yang kemudian membuka jalan bagi penafsiran Pancasila secara bebas dan sesuka hati sehingga menjadi sumber segala penyelewengan didalam sejarah ketatanegaraan Indonesia (Darmodiharjo, Ed., 1991: 146). Penyederhanaan redaksi pancasila tersebut menimbulkan multi tafsir dan mereduksi cita-cita kemerdekaan berlandaskan pancasila seperti yang termuat dalam pembukaan UUD 1945. Misalkan pada sila keempat: konsep hikmat kebijaksanaan dalam Permusyawaratan/Perwakilan telah ditiadakan, sehingga konstituante tidak mampu bersepakat dalam sidang-sidangnya. Atau barangkali juga terhadap sila ketiga: persatuan Indonesia, dimana dalam sidangsidang konstituante selalu diwarnai dengan perdebatan sengit, para anggota Badan Konstituante lebih banyak mementingkan urusan partainya sendiri daripada kepentingan rakyat.

Perubahan redaksi Pancasila dalam mukadimah konstitusi RIS dan UUDS 1950 menimbulkan pertanyaan besar, bagaimana 
eksistensi pancasila pada masa RIS dan Demokrasi Liberal 1950-1959? Untuk pertanyaan itu, ada dua jawaban utama yaitu: pertama, Pancasila tetap eksis sebagai dasar negara oleh sebab perubahan itu "hanya" dalam tataran kata bukan jiwanya. Hal itu terlihat dari pendapat konstituante 1959 dimana sidang berpendapat bahwa:

"...yang penting dalam UUD 1945 bukanlah sekadar Babbabnya, bukanlah sekadar pasal-pasalnya, bukan sekedar rumusanrumusannya, bukanlah sekadar kata-katanya, tetapi jiwanya, semangatnya, kepribadian bangsa Indonesia dan amanat penderitaan rakyat Indonesia yang mewahyui konstitusi proklamasi 17 Agustus 1945 itu."

(Konstituante RI, dalam Tambunan, 1993: 40)

UUD 1945 adalah sebuah kesatuan antara pembukaan dan batang tubuh meskipun secara eksplisit merujuk kepada batang tubuh UUD namun secara implisit termasuk pula pembukaan.

Jawaban kedua, Pancasila tidak eksis dan yang tercantum dalam mukadimah Konstitusi RIS dan UUDS 1959 adalah pancasila palsu (Hazairin, 1990: 36). Jawaban ini kurang populis, namun sayangnya benar. Redaksi Pancasila adalah sebuah produk final yang ditetapkan dalam sidang para pendiri bangsa 18 Agustus 1945. Redaksi itu penting, itulah sebabnya hingga para pendiri bangsa merasa perlu untuk merubah frasa "Ke-Tuhanan dengan kewajiban menjalankan Syari'at Islam bagi pemeluk-pemeluknya" menjadi "Ketuhanan Yang Maha Esa”. Maka Pancasila yang final adalah Pancasila sebagaimana yang tercantum dalam pembukaan UUD 1945, yang ditetapkan 18 Agustus 1945, bukan Pancasila piagam

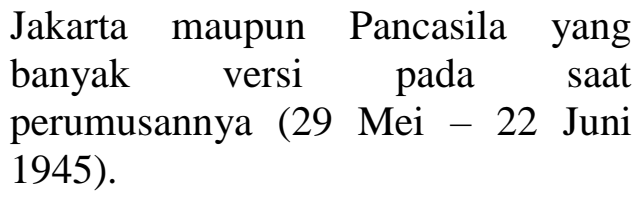

\section{E. AMANDEMEN PEMBUKAAN UUD}

Dewasa ini, sebagai staatsidee, pembukaan UUD 1945 tidak boleh diganggu gugat dan itu dapat diterima oleh banyak kalangan termasuk para ahli hukum tata negara. Pancasila sebagai dasar negara dan ideologi bangsa tidak termuat dalam dokumen tersendiri, ia hadir, menjiwai dan tercantum dalam pembukaan UndangUndang Dasar. Oleh karena itu "Pembukaan UUD 1945 mengandung Staatsidee berdirinya Negara Kesatuan Republik Indonesia (NKRI), tujuan (haluan) negara serta dasar negara yang harus tetap dipertahankan" (Setjend MPR RI, 2011:19). Merubah pembukaan UUD pada dasarnya menganulir negara lama dan kemudian mendirikan negara baru di atasnya.

Namun pendapat itu lebih mendekati sebagai trauma terhadap mukadimah RIS dan UUDS 1950 yang nyata-nyata telah merubah UUD. Padahal secara konstitusi, MPR berwenang untuk mengadakan perubahan tersebut. Seperti yang tercantum dalam UUD 1945 pasal 37 ayat 1: "Untuk mengubah UndangUndang Dasar sekurang-kurangnya 2/3 daripada jumlah anggota Majelis Permusyawaratan Rakyat harus hadir". Jika kita konsisten menyatakan bahwa UUD adalah kesatuan antara Pembukaan dan Batang Tubuh, maka pasal itu tentu berlaku pula terhadap pembukaan. Lagipula pasal itu tidak menyatakan "untuk mengubah batang tubuh Undang-Undang Dasar...", sehingga mensakralkan pembukaan UUD 1945 adalah tidak memiliki dasar.

Kita ambil contoh misalkan India, yang telah melakukan amandemen terhadap Preamble Konstitusinya. India adalah contoh negara yang "dimerdekakan", maka lazim bila staatsidee-nya termaktub dalam pembukaan Undang-Undang Dasar-nya. Seperti dapat dijelaskan 
sebagai berikut (www.constitutions.org, 2014a):

WE, THE PEOPLE OF INDIA, having solemnly resolved to constitute India into a SOVEREIGN DEMOCRATIC REPUBLIC and to secure to all its citizens:

JUSTICE, social, economic and political;

LIBERTY of thought, expression, belief, faith and worship; opportunity;

EQUALITY of status and of and to promote among them all

FRATERNITY assuring the dignity of the individual and the unity of the Nation;

IN OUR CONSTITUENT ASSEMBLY this twenty-sixth day of November, 1949, do HEREBY ADOPT, ENACT AND GIVE TO OURSELVES

THIS CONSTITUTION.

-Pembukaan Konstitusi

India

sebelum Amandemen

WE, THE PEOPLE OF INDIA, having solemnly resolved to constitute India into a SOVEREIGN SOCIALIST

SECULAR

DEMOCRATIC REPUBLIC and to secure to all its citizens:

JUSTICE, social, economic and political;

LIBERTY of thought, expression, belief, faith and worship; opportunity;

EQUALITY of status and of and to promote among them all

FRATERNITY assuring the dignity of the individual and the unity and integrity of the Nation;

IN OUR CONSTITUENT ASSEMBLY this twenty-sixth day of November, 1949, do HEREBY ADOPT, ENACT AND GIVE TO OURSELVES THIS CONSTITUTION.

-Pembukaan Konstitusi

India

setelah Amandemen 1977
Dari teks pembukaan konstitusi India tersebut terlihat bahwa, staatsidee termaktub didalamnya, yaitu: Justice (Keadilan), Liberty (Kebebasan), Equality (Kesetaraan), dan Fraternity (Persaudaraan). Namun meskipun demikian, melakukan amandemen terhadap pembukaan tersebut bukan suatu yang tabu di India. Seperti yang terjadi saat amandemen konstitusi ke-42 pada tahun 1976. Setidaknya terdapat dua hal yang diamandemen pada pembukaan, yaitu bentuk negara dari Republik Demokratis Berdaulat menjadi Republik Demokratis Sosialis Sekuler Berdaulat. Yang kedua adalah bentuk kebangsaan dari negara berdasarkan Persatuan Bangsa, diperkukuh dengan Persatuan dan Kesatuan Bangsa. Tentu ada pertimbangan mendalam kenapa MPR India merasa perlu untuk merubah, atau menegaskan bahwa India adalah negara Sosialis Sekuler dan tidak sekedar negara Persatuan melainkan juga negara Kesatuan.

Sedangkan, jika Pembukaan UUD Indonesia disejajarkan dengan Preamble Konstitusi Amerika tidaklah tepat, alasannya selain disana tidak termaktub staatsidee negara Amerika, Preamble itu sangat singkat dan tidak memuat hal-hal prinsip. Preamble itu adalah sebagai berikut (www.constitutions.org, 2014b):

We the People of the United States, in Order to form a more perfect Union, establish Justice, insure domestic Tranquility, provide for the common defence, promote the general Welfare, and secure the Blessings of Liberty to ourselves and our Posterity, do ordain and establish this Constitution for the United States of America.

Staatsidee Amerika tidak terdapat dalam Preambe Konstitusi melainkan dalam Declaration of Independence. Deklarasi kemerdekaan adalah hal final, sebuah kenyataan sejarah, oleh karenanya wajar jika Declaration of Independence dalam hal ini termasuk staatsidee didalamnya 
adalah suatu hal yang tidak dapat direvisi. Namun itu lebih sebagai kenyataan sejarah yang einmalig, bukan karena didalamnya terdapat staatsidee. Hal ini sama halnya dengan Proklamasi Kemerdekaan 17 Agustus 1945, merevisi proklamasi adalah keniscayaan karena ia adalah sebuah kenyataan sejarah.

Poin pentingnya adalah mengamandemen pembukaan UUD, sekalipun didalamnya terdapat staatsidee, dan bahkan perubahan tersebut mengenai hal yang sangat fundamental adalah suatu hal yang wajar, rasional dan memungkinkan.

\section{F. KESIMPULAN}

Staatsidee Negara Kesatuan Republik Indonesia tidak terdapat dalam Proklamasi, melainkan dalam Pembukaan UUD 1945. Namun demikian itu tidak serta merta menjadi alasan bahwa Pembukaan itu sakral karena mengandung staatsidee, karena perubahan atau amandemen terhadapnya telah dijamin dalam Undang-Undan Dasar.

Kejanggalan-kejanggalan

Pembukaan UUD Negara Kesatuan Republik Indonesia antara lain terdapat ambigu tentang pernyataan kemerdekaan antara pada Proklamasi atau Pembukaan UUD 1945. Kejanggalan yang lain adalah inkonsistensi penggunaan kata Allah dan Tuhan. Kejanggalan selanjutnya adalah panggantian terhadap naskah pembukaan UUD sehingga berarti pula penggantian terhadap staatsidee yaitu Pancasila.

$$
\text { Amandemen terhadap }
$$

Pembukaan UUD Negara Kesatuan Republik Indonesia adalah kemungkinan yang rasional dan berlandaskan hukum. Sebaliknya pengsakralan terhadapnya adalah sebuah mitos yang tidak berdasar hukum. Kejanggalan pembukaan UUD 1945 dan kemungkinan tuntutan zaman yang berbeda seharusnya memungkinkan untuk tetap memberikan peluang terhadap
Amandemen UUD, termasuk didalamnya adalah Pembukaan.

\section{DAFTAR PUSTAKA}

Asshiddiqie, Jimly. (Tanpa Tahun). Ideologi, Pancasila, dan Konstitusi. Makalah tersedia di http://www.jimly.com/pemikiran/ma kalah?page $=15$ diakses 03/05/2014 13:43

Darmodiharjo, Darji., dkk. Ed. (1991). Santiaji Pancasila. Surabaya: Usaha Nasional

Denni. (2013). Unsur-unsur Terbentuknya Sebuah Negara. Tersedia di http://blogdenni.wordpress.com/unsu r-unsur-terbentuknya-negara/ diakses 03/05.2014 15:20

Hazairin, (1990). Demokrasi Pancasila. Jakarta: Rineka Cipta.

Raharjo, Said. (2013). Cita Negara, Hukum Pancasila, Pembukaan, dan Penjelasan UUD 1945. Makalah tersedia di http://layananguru.blogspot.com/2013/01/makalah -cita-negara-hukum-pancasila.html diakses 03/05/2014 13:57

Sekretariat Jenderal MPR RI, (2001). Panduan Pemasyarakatan UndangUndang Dasar Negara Republik Indonesia Tahun 1945 dan Ketetapan Majelis Permusyawaratan Rakyat Republik Indonesia. Jakarta: Setjend MPR RI.

Tambunan. (1993). Dualisme Naskah UUD 1945. Jakarta: Pustaka Sinar Harapan.

Wikipedia, Indonesia. (2014). Badan Penyelidik Usaha-usaha Persiapan Kemerdekaan Indonesia. Tersedia di http://id.wikipedia.org/wiki/BPUPKI diakses 03/05/2014 22:10

www.constitutions.org. (2014a). The Constitution Of India. Tersedia di http://www.constitution.org/cons/ind ia/const.html 06/05/2014 16:09

www.constitutions.org. (2014b). Constitution for the United States of America. Tersedia di http://www.constitution.org/constit . htm 06/05/2014 16:44 
Volume 4 No 1 Maret 2018 